\title{
Cardio-vascular vital sign measurements could be reduced in number during the drug allergy work-up
}

\author{
WITCHAYA SRISUWATCHARI ${ }^{1}$, Amelie Gauthier ${ }^{1}$, Marion Menanteau ${ }^{1}$, Pascal \\ Demoly $^{1}$, and Anca Chiriac ${ }^{1}$ \\ ${ }^{1}$ Division of Allergy
}

July 30, 2020

To the Editor,

Drug provocation test (DPT) is considered the gold standard test to diagnose drug hypersensitivity reactions (DHR), in absence of contraindications. However, it may be very time consuming. The procedure usually consists in the administration of a medication with cautious incremental doses under close medical observation. ${ }^{1-4}$ Vital sign measurements (e.g., blood pressure (BP), pulse) and surveillance of the patient' symptoms and signs are usually performed several times during the entire procedure to capture and prevent as soon as possible any severe reaction. However, learned societies only set a frame for DPT performance and do not make specific recommendations about the type and rhythm of these measurements. ${ }^{1,}{ }^{3,4}$ In our center, data-driven DPT (i.e., based on patterns of reactions detected through Kaplan Meier curves) is performed in 4-7 step dosing for beta-lactams (BL), ${ }^{5}$ 2-6 steps for nonsteroidal anti-inflammatory drugs (NSAID) ${ }^{6}{ }^{3} 3-4$ steps for paracetamol, ${ }^{7}$ and 5-7 steps for fluoroquinolones (article in press), with time increments of 30 or 60 minutes (up to $3 \mathrm{~h}$ for certain NSAID). The BL pattern is generally applied to DPTs for other drugs. Empirically, we considered the measurement of BP and pulse as mandatory and required before starting the DPT, before every incremental dose and at any time during the DPT if symptoms of a DHR occurred. We presumed this would ensure the best safety for patients undergoing DPT, particularly for those with immediate severe reactions, namely anaphylaxis with or without shock. However, the benefit of such an attitude in patients with non-immediate reactions or immediate non-severe reactions could be questioned and to the best of our knowledge, no study has been published on this issue. In addition, measurement of $\mathrm{BP}$ during $\mathrm{ST}$ is not common practice.

During the past two decades of our center experience, based on clinical observation and previous analyses, ${ }^{8,9}$ we observed that isolated symptoms and signs evocative of shock during drug allergy work-up are very rare. Patients usually presented those signs in conjunction with symptoms and signs from other systems, including mucocutaneous (CU), respiratory (RS), and gastrointestinal (GI). Therefore, we hypothesized that $\mathrm{BP}$ measurement could be reduced in number in some circumstances, according to risk stratification (that we presumed related to the patient's individual situation and involved drug class). This retrospective analysis was then carried out in order to identify cases with symptoms and signs evocative of shock during drug allergy investigation in our center. The patients (or their parents, in case of children) gave their written informed consent at the time of the allergy work-up for their anonymous data to be used for research purposes.

We conducted a retrospective analysis using data retrieved from the Drug Allergy and Hypersensitivity Database (DAHD) between January 1996 and June 2019 in the Allergy Unit of the University Hospital of Montpellier, France. Patients with suspicions of DHR who underwent drug allergy work-up and presented with symptoms and signs evocative of shock during the tests were included in the analysis. The search terms included: "malaise", "hypotension", "collapse", "loss of consciousness", and "unspecified cardiovascular problem". Drug allergy work-up including skin test (ST) and DPT was performed according to the European 
Network of Drug Allergy (ENDA) recommendations.

During the study period, 10198 patients were tested with 53059 single tests (a single test is defined as ST or DPT for an allergen). A total of 32 patients (0.3\%) (9 males, mean age at tests of $37.0 \pm 14.9$ years) with 36 reactions $(0.06 \%)$ who presented with the above mentioned cardiovascular (CV) signs/symptoms were identified (31 during DPT, 5 during ST). Antibiotics were the most frequent drug classes involved (47.2\%), followed by NSAIDs (13.9\%), and paracetamol (13.9\%) (Supplementary Table 1). Among these reactions, 4 were found to be isolated CV signs/symptoms (3/11000 DPT (0.03\%), and 1/42059 ST (0.002\%), while CV with other systemic signs/symptoms were present in 32 reactions (88.9\%). (Table 1 and Supplementary Text 1)

Using retrospective analysis from the DAHD during the past 25 years, we have demonstrated that patients with CV symptoms and signs evocative of a severe immediate DHR (shock) during the drug allergy investigation are rare, namely $0.3 \%$ of all tested patients and $0.06 \%$ of all single tests. Amongst them, only 4 patients $(0.04 \%)$ with 4 reactions $(0.007 \%)$ were found to have isolated CV signs/symptoms. Whether these signs were markers of true DHR could be debatable for patients no. 1 (considering her multiple similar episodes, ruled out by further investigations) and no. 3 , while patient no. 4 developed anaphylactic shock during positive ST to BL drugs (meaning that the systemic symptoms were associated to positivity at the injection site). Therefore, only one case (patient no. 2) could be classified as having isolated CV signs/symptoms as an allergic reaction.

Based on this analysis and previous analyses of patterns of reactivity and severity during DPT for different drug classes (e.g., BL, NSAIDs, paracetamol, quinolones), we propose criteria to reduce the frequency of BP measurements during DPT, according to risk stratification based on patient clinical history and drug class. Clinical history could be classified into three categories: immediate severe (high risk), immediate non-severe (low risk), and non-immediate non-severe (low risk) reactions (i.e., severe non-immediate reactions being classical contraindications to DPT). ${ }^{3}$ Regarding drug class, we based our risk stratification on previous studies tackling patterns of DPT reactions to BL, NSAIDs, paracetamol and quinolones showing that the frequency of anaphylaxis elicited by DPT was $15 \%, 10 \%, 25 \%$ and $20 \%$ respectively. ${ }^{5-7}$ For NSAIDs, the immediate non-severe reaction (e.g., urticaria, angioedema, rhino-conjunctivitis) is a typical clinical presentation and for such an index reaction, $90 \%$ of the positive DPT are benign cutaneous reactions (6). Thus, NSAIDs could be classified as low risk drug class. Therefore, the criteria of BP measurement could be categorized as in Table 2. Regarding our 4 patients with isolated CV symptoms, all of them would've been classified in the high-risk groups (patient no. 1 and no. 3 because of index history of immediate severe reaction, patient no. 2 and no. 4 because of the drug class).

It could be argued that by reducing the number of CV vital signs measurements, the professional performing the DPT could be distracted from the very core of the allergy work-up, which is ensuring patient safety during the procedures. However, our study shows that isolated CV signs/symptoms are extremely rare during the drug allergy work-up performed according to safety recommendations (i.e., step-wise exposure to allergen). In contrast, the decrease in this technical workload could be beneficial to patients because physicians/nurses would then have more time to concentrate on patient questioning and reassurance during the tests. In addition, the reduction of this measurement could reduce the uncomfortable, or painful feeling of the BP measurement, particularly for young children.

To the best of our knowledge, this is the first study specifically addressing the outcome of the BP measurement during drug allergy work-up in an evidence-based manner. Reporting and analyzing the rarity of cases with isolated CV signs/symptoms enabled us to propose 4 frames for BP measurement. In a prospective trial for 1 month, BP frequency could be reduced by $14.3 \%$ (range 10.3-26.5), alleviating the technical task and favoring the medical one instead. The prospective evaluation is ongoing in our center.

In conclusion, patients with symptoms and signs evocative of shock are extremely rare during drug allergy work-up, therefore BP measurement could be reduced in number according to patient clinical history of DHR and drug class risk stratification. 


\section{References}

1. Aberer W, Bircher A, Romano A, Blanca M, Campi P, Fernandez J, et al. Drug provocation testing in the diagnosis of drug hypersensitivity reactions: general considerations. Allergy. 2003;58:854-863.

2. Demoly P, Adkinson NF, Brockow K, Castells M, Chiriac AM, Greenberger PA, et al. International Consensus on drug allergy. Allergy. 2014;69:420-437.

3. Romano A, Atanaskovic-Markovic M, Barbaud A, Bircher AJ, Brockow K, Caubet JC, et al. Towards a more precise diagnosis of hypersensitivity to beta-lactams - an EAACI position paper. Allergy. 2020;75:13001315 .

4. Joint Task Force on Practice Parameters; American Academy of Allergy, Asthma and Immunology; American College of Allergy, Asthma and Immunology; Joint Council of Allergy, Asthma and Immunology. Drug allergy: an updated practice parameter. Ann Allergy Asthma Immunol. 2010;105:259-273.

5. Chiriac AM, Rerkpattanapipat T, Bousquet PJ, Molinari N, Demoly P. Optimal step doses for drug provocation tests to prove beta-lactam hypersensitivity. Allergy. 2017;72:552-561.

6. Nohra D, Molinari N, Demoly P, Chiriac AM. Data-driven step doses for drug provocation tests to nonsteroidal anti-inflammatory drugs. Allergy. 2020;75:1423-1434.

7. Nohra D, Schrijvers R, Touati N, Nahas O, Ben Fadhel N, Ferrando L, et al. Risk factors for positive paracetamol drug provocation testing and procedure optimization. J Allergy Clin Immunol Pract. 2019;7:20452048.e2042.

8. Messaad D, Sahla H, Benahmed S, Godard P, Bousquet J, Demoly P. Drug provocation tests in patients with a history suggesting an immediate drug hypersensitivity reaction. Ann Intern Med. 2004;140:1001-1006.

9. Rubio M, Bousquet PJ, Gomes E, Romano A, Demoly P. Results of drug hypersensitivity evaluations in a large group of children and adults. Clin Exp Allergy. 2012;42:123-130.

Witchaya Srisuwatchari, $\mathrm{MD}^{1,2}$, Amélie Gauthier, $\mathrm{MD}^{1,3}$, Marion Menanteau, $\mathrm{MD}^{1,4}$, Pascal Demoly, MD, $\mathrm{PhD}^{1,5}$, Anca Mirela Chiriac, $\mathrm{MD}, \mathrm{PhD}^{1,5}$

\section{Author's affiliation:}

${ }^{1}$ Division of Allergy, Department of Pulmonology, Hôpital Arnaud de Villeneuve, University Hospital of Montpellier, Montpellier, France

2 Division of Allergy and Immunology, Department of Pediatrics, Faculty of Medicine Siriraj Hospital, Mahidol University, Bangkok, Thailand

3 Department of Allergy and Immunology, Laval University Hospital Center, Laval University, Quebec City, Canada

${ }^{4}$ Division of Allergy, Department of Pneumology, Larrey University Hospital, Toulouse, France

${ }^{5}$ UMR-S 1136 INSERM-Sorbonne Université, Equipe EPAR - IPLESP, Paris, France

\section{Corresponding author:}

Dr Witchaya Srisuwatchari

Witchaya.sr@gmail.com

Tel: (+66) 2-419-5670

Division of Allergy and Immunology, Department of Pediatrics

Faculty of Medicine Siriraj Hospital, Mahidol University

2 Prannok Road, Bangkoknoi, Bangkok 10700, Thailand 
Words: 1224

Conflict of interest : None for this paper

Funding information: None

Keywords: Anaphylaxis, Challenge test, Drug allergy

\section{Authors' contributions}

WS, AG, MM, PD, and AMC designed the study. WS and AMC collected and analyzed the data. WS, AG, and AMC wrote the first draft of the manuscript. All authors participated in a critical review and revision of the manuscript. All authors have read and approved the final version of the manuscript.

Table 1. Characteristics of the patients with cardio-vascular symptoms and signs evocative of shock and their drug allergy work-up results

\begin{tabular}{|c|c|c|c|c|c|c|c|c|c|}
\hline $\begin{array}{l}\text { Patient } \\
\text { No. }\end{array}$ & Sex & $\begin{array}{l}\text { Age at } \\
\text { tests (Yr) }\end{array}$ & Year (Yr) & $\begin{array}{l}\text { Drug } \\
\text { tested }\end{array}$ & $\begin{array}{l}\text { Type of } \\
\text { test }\end{array}$ & $\begin{array}{l}\text { Chronology } \\
\text { of the } \\
\text { reaction }\end{array}$ & $\begin{array}{l}\text { Symptoms } \\
\text { and signs } \\
\text { during } \\
\text { drug } \\
\text { allergy } \\
\text { work-up }\end{array}$ & $\begin{array}{l}\text { Symptoms } \\
\text { and signs } \\
\text { during } \\
\text { drug } \\
\text { allergy } \\
\text { work-up }\end{array}$ & $\begin{array}{l}\text { Symptoms } \\
\text { and signs } \\
\text { during } \\
\text { drug } \\
\text { allergy } \\
\text { work-up }\end{array}$ \\
\hline & & & & \multirow{2}{*}{\multicolumn{2}{|c|}{ AspartameDPT }} & & CV & $\mathbf{C U}$ & RS \\
\hline 1 & $\mathbf{F}$ & 29 & 1998 & & & $1-6 h$ & $\begin{array}{l}\text { malaise } \\
\text { with- } \\
\text { out } \\
\text { hy- } \\
\text { poten- } \\
\text { sion }\end{array}$ & - & - \\
\hline 2 & $\mathbf{F}$ & 17 & 2013 & \multicolumn{2}{|c|}{ CefuroximdPT } & $<1 \mathrm{~h}$ & $\begin{array}{l}\text { malaise } \\
\text { hy- } \\
\text { poten- } \\
\text { sion }\end{array}$ & - & - \\
\hline 3 & $\mathbf{F}$ & 24 & 2011 & \multirow{2}{*}{\multicolumn{2}{|c|}{$\begin{array}{l}\text { DexamethadifiE } \\
\text { AmoxicillinsT } \\
\text { PPL, } \\
\text { MDM }\end{array}$}} & $<1 \mathrm{~h}$ & \multicolumn{2}{|c|}{ hypotension } & - \\
\hline 4 & $\mathbf{F}$ & 32 & 2000 & & & $<1 \mathrm{~h}$ & \multicolumn{2}{|c|}{$\begin{array}{l}\text { hypotension, } \\
\text { collapse, } \\
\text { loss of } \\
\text { con- } \\
\text { scious- } \\
\text { ness }\end{array}$} & - \\
\hline 5 & $\mathrm{~F}$ & 34 & 2002 & $\begin{array}{l}\text { Lidocaine } \\
\text { chlorhy- } \\
\text { drate/ } \\
\text { Benza- } \\
\text { lko- } \\
\text { nium } \\
\text { chlorure }\end{array}$ & $\mathrm{DPT}$ & $1-6 \mathrm{~h}$ & malaise & urticaria & - \\
\hline & & 34 & 2002 & Pholcodine & DPT & $1-6 \mathrm{~h}$ & malaise & $\begin{array}{l}\text { isolated } \\
\text { pruritus }\end{array}$ & - \\
\hline 6 & $\mathrm{~F}$ & 30 & 2002 & \multicolumn{2}{|c|}{$\begin{array}{l}\text { ParacetamoløPT } \\
\text { codeine }\end{array}$} & $1-6 \mathrm{~h}$ & malaise & urticaria & dyspnea \\
\hline
\end{tabular}




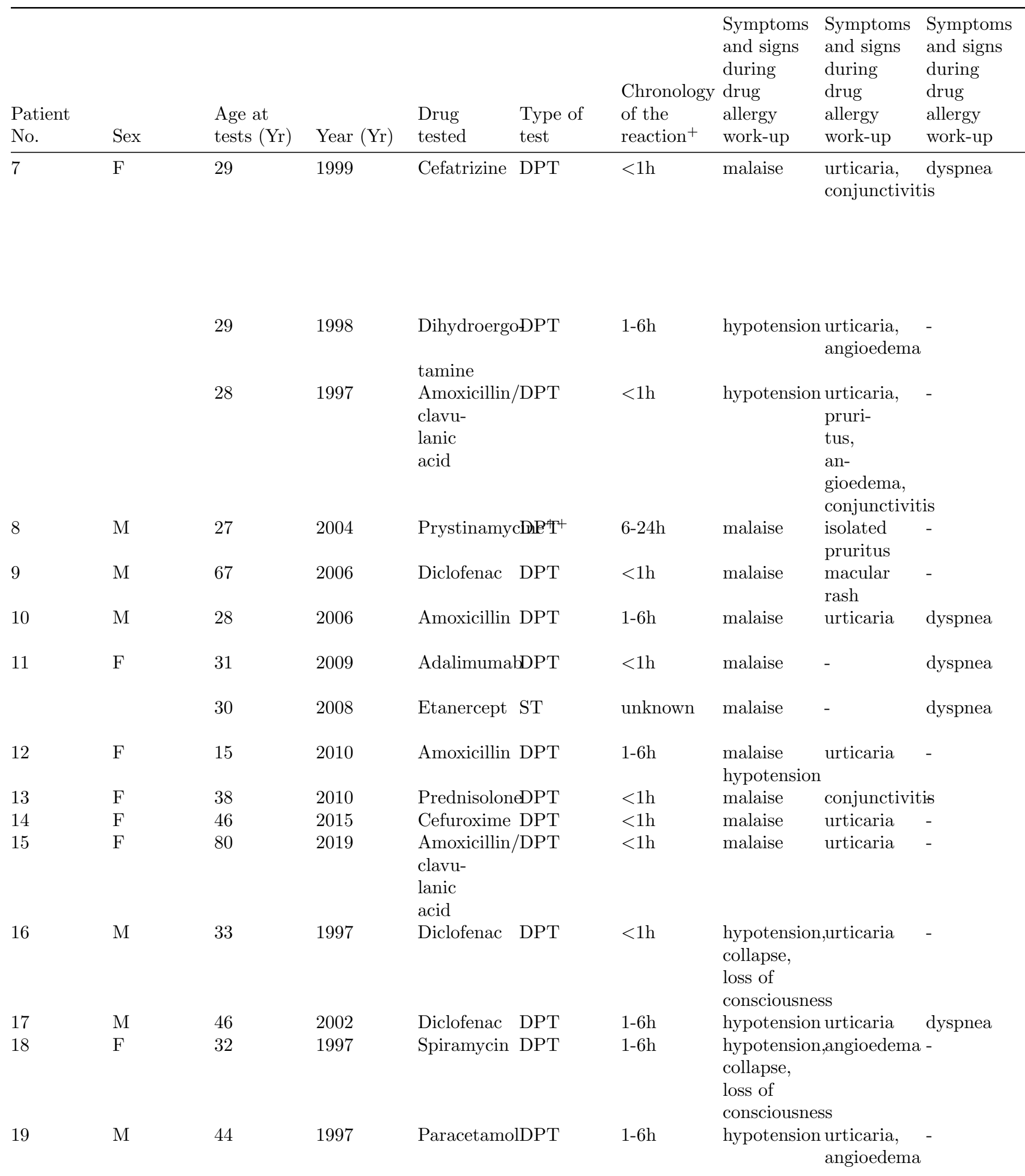




\begin{tabular}{|c|c|c|c|c|c|c|c|c|c|}
\hline $\begin{array}{l}\text { Patient } \\
\text { No. }\end{array}$ & Sex & $\begin{array}{l}\text { Age at } \\
\text { tests (Yr) }\end{array}$ & Year $(\mathrm{Yr})$ & $\begin{array}{l}\text { Drug } \\
\text { tested }\end{array}$ & $\begin{array}{l}\text { Type of } \\
\text { test }\end{array}$ & $\begin{array}{l}\text { Chronology } \\
\text { of the } \\
\text { reaction }\end{array}$ & $\begin{array}{l}\text { Symptoms } \\
\text { and signs } \\
\text { during } \\
\text { drug } \\
\text { allergy } \\
\text { work-up }\end{array}$ & $\begin{array}{l}\text { Symptoms } \\
\text { and signs } \\
\text { during } \\
\text { drug } \\
\text { allergy } \\
\text { work-up }\end{array}$ & $\begin{array}{l}\text { Symptoms } \\
\text { and signs } \\
\text { during } \\
\text { drug } \\
\text { allergy } \\
\text { work-up }\end{array}$ \\
\hline 20 & $\mathrm{M}$ & 30 & 2004 & Cefatrizine & DPT & $1-6 \mathrm{~h}$ & \multicolumn{3}{|c|}{$\begin{array}{cc}\text { hypotension macular } & \text { dy } \\
\text { rash, } & \text { co } \\
\text { conjunctivitis }\end{array}$} \\
\hline 21 & $\mathrm{~F}$ & 57 & 2005 & Paracetamol & lDPT & $1-6 \mathrm{~h}$ & \multicolumn{3}{|c|}{$\begin{array}{l}\text { hypotension maculopapular } \\
\text { rash, } \\
\text { pruritus }\end{array}$} \\
\hline 22 & M & 33 & 2006 & Ceftriaxone & $\mathrm{DPT}$ & $1-6 \mathrm{~h}$ & hypotensior & $\begin{array}{l}\text { isolated } \\
\text { pruritus }\end{array}$ & - \\
\hline 23 & $\mathrm{~F}$ & 30 & 2008 & Ketoprofen & $\mathrm{DPT}$ & $1-6 \mathrm{~h}$ & hypotensior & $\begin{array}{l}\text { urticaria, } \\
\text { an- } \\
\text { gioedema, } \\
\text { conjunctivit }\end{array}$ & is \\
\hline 24 & $\mathrm{~F}$ & 51 & 2009 & \multicolumn{2}{|c|}{ ParacetamolDPT } & $1-6 \mathrm{~h}$ & \multirow{4}{*}{\multicolumn{2}{|c|}{$\begin{array}{c}\text { hypotension urticaria } \\
\text { hypotension urticaria } \\
\text { hypotension urticaria } \\
\text { hypotension macular } \\
\text { rash, } \\
\text { pruritus }\end{array}$}} & - \\
\hline 25 & $\mathrm{~F}$ & 38 & 2012 & Rifampicin & $\mathrm{DPT}$ & $<1 \mathrm{~h}$ & & & - \\
\hline 26 & $\mathrm{~F}$ & 22 & 2012 & Paracetamol & lDPT & $1-6 \mathrm{~h}$ & & & dyspnea \\
\hline 27 & $\mathrm{~F}$ & 8 & 2000 & Cefatrizine & DPT & $<1 \mathrm{~h}$ & & & - \\
\hline 28 & $\mathrm{~F}$ & 61 & 2001 & Pholcodine & $\mathrm{DPT}$ & $1-6 \mathrm{~h}$ & \multicolumn{3}{|c|}{$\begin{array}{l}\text { hypotension urticaria, } \\
\text { an- } \\
\text { gioedema, } \\
\text { conjunctivitis }\end{array}$} \\
\hline 29 & M & 45 & 2019 & Ibuprofen & $\mathrm{DPT}$ & $1-6 \mathrm{~h}$ & \multicolumn{3}{|c|}{$\begin{array}{c}\text { hypotension urticaria dyspnea } \\
\text { conjunctivitis }\end{array}$} \\
\hline 30 & $\mathrm{~F}$ & 51 & 2000 & $\mathrm{BL}$ & $\mathrm{ST}$ & $<1 \mathrm{~h}$ & \multicolumn{3}{|c|}{$\begin{array}{r}\text { hypotension pruritus, - } \\
\text { conjunctivitis }\end{array}$} \\
\hline 31 & $\mathrm{~F}$ & 54 & 2002 & Cefradine & $\mathrm{ST}$ & $<1 \mathrm{~h}$ & \multirow{2}{*}{\multicolumn{3}{|c|}{$\begin{array}{l}\text { hypotension angioedema bronchospa } \\
\text { hypotension urticaria, dyspnea } \\
\text { conjunctivitis }\end{array}$}} \\
\hline 32 & $\mathrm{~F}$ & 49 & 2017 & $\mathrm{BL}$ & $\mathrm{ST}$ & $<1 \mathrm{~h}$ & & & \\
\hline
\end{tabular}




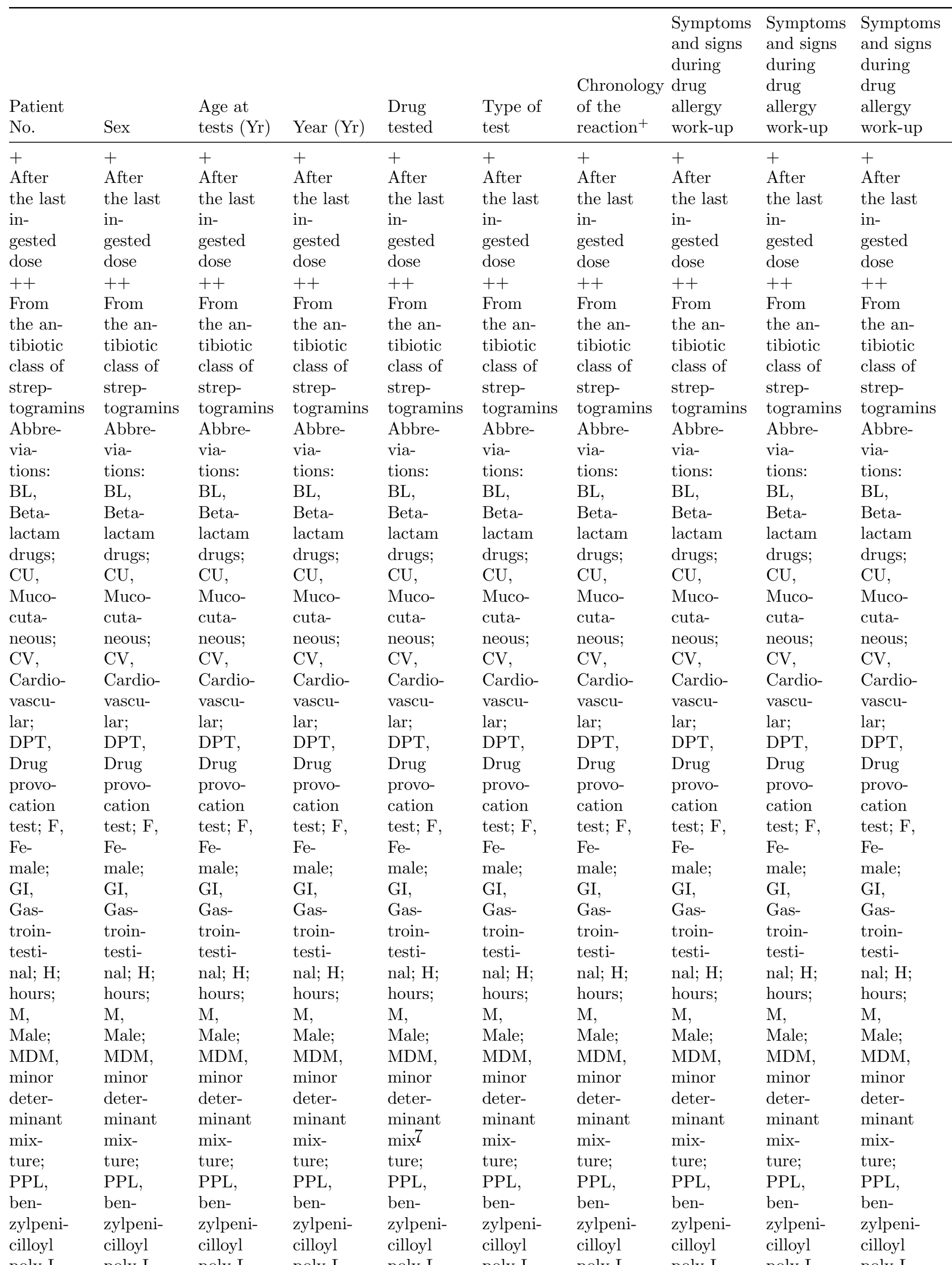




\begin{tabular}{|c|c|c|c|}
\hline $\begin{array}{l}\text { Age at } \\
\text { tests (Yr) }\end{array}$ & Year (Yr) & $\begin{array}{l}\text { Type of } \\
\text { test }\end{array}$ & $\begin{array}{lll} & \begin{array}{l}\text { Symptoms } \\
\text { and signs } \\
\text { during }\end{array} & \begin{array}{l}\text { Symptoms } \\
\text { and signs } \\
\text { during }\end{array} \\
\text { Chronology } & \text { drug } & \text { drug } \\
\text { of the } & \text { allergy } & \text { allergy } \\
\text { reaction }^{+} & \text {work-up } & \text { work-up }\end{array}$ \\
\hline \multicolumn{4}{|c|}{$\begin{array}{l}\text { Table 2. Proposed criteria of BP measurement according to risk stratification based on patient } \\
\text { clinical history and drug class. }\end{array}$} \\
\hline Clinical history of patients & \multicolumn{2}{|l|}{ Drug class } & Criteria of BP measurement \\
\hline $\begin{array}{l}\text { Patients with clinical history of } \\
\text { immediate severe reaction }\end{array}$ & \multicolumn{2}{|l|}{ Any drug } & \multirow{2}{*}{$\begin{array}{l}\text { Perform BP measurement } \\
\text { before every step dose } \\
\text { Perform BP measurement before } \\
\text { every step dose }\end{array}$} \\
\hline $\begin{array}{l}\text { Patients with clinical history of } \\
\text { immediate non-severe reaction }\end{array}$ & \multicolumn{2}{|c|}{ Any drug ${ }^{+}$(except NSAIDs) } & \\
\hline & \multicolumn{2}{|l|}{ NSAIDs } & $\begin{array}{l}\text { Perform BP measurement } \\
\text { before the first and the last dose }\end{array}$ \\
\hline $\begin{array}{l}\text { Patients with clinical history of } \\
\text { non-immediate reaction }\end{array}$ & \multicolumn{2}{|l|}{ Any drug } & $\begin{array}{l}\text { Perform BP measurement } \\
\text { before the first and the last dose }\end{array}$ \\
\hline $\begin{array}{l}\text { Abbreviations: BP, blood } \\
\text { pressure; NSAIDs, nonsteroidal } \\
\text { anti-inflammatory drugs }+ \text { By } \\
\text { default, because of lack of } \\
\text { substantial data for most drug } \\
\text { classes, we consider that any } \\
\text { immediate reaction, even the } \\
\text { non-severe ones, could be } \\
\text { immune-mediated }\end{array}$ & \multicolumn{2}{|c|}{$\begin{array}{l}\text { Abbreviations: BP, blood } \\
\text { pressure; NSAIDs, nonsteroidal } \\
\text { anti-inflammatory drugs }+ \text { By } \\
\text { default, because of lack of } \\
\text { substantial data for most drug } \\
\text { classes, we consider that any } \\
\text { immediate reaction, even the } \\
\text { non-severe ones, could be } \\
\text { immune-mediated }\end{array}$} & $\begin{array}{l}\text { Abbreviations: BP, blood } \\
\text { pressure; NSAIDs, nonsteroidal } \\
\text { anti-inflammatory drugs }+ \text { By } \\
\text { default, because of lack of } \\
\text { substantial data for most drug } \\
\text { classes, we consider that any } \\
\text { immediate reaction, even the } \\
\text { non-severe ones, could be } \\
\text { immune-mediated }\end{array}$ \\
\hline
\end{tabular}

\section{Supplementary Text 1: Detailed description of the four reactions of four patients who presented isolated cardio-vascular symptoms and signs evocative of shock during drug allergy work-up.}

Patient no. 1 was a 29-year-old female who reported a history of discomfort, edema of the neck, difficulty breathing, paresthesia of the lower limbs, hands, and face, and mild erythematous eruption on the chest and neck, 3-4h after taking aspartame in coffee. After the third DTP dose of $1 \mathrm{mg}$ (cumulative dose of 1.22 mg aspartame), she developed the same feeling of discomfort, malaise, without hypotension. The symptoms persisted for $1 \mathrm{~h}$ and disappeared spontaneously. The patient then refused to continue the test. She had been previously considered allergic to clavulanic acid and dihydro-ergotamine, based on objective symptoms occurring during DPT with these drugs. Years after her initial allergy work-up, she reported similar episodes to misoprostol, cefuroxime, and pristinamycin (a synergistin antibiotic). However, after DPT, no other DHR could be confirmed. She was also investigated for endocrine abnormalities, without any abnormal test result.

Patient no. 2 was a 17 -year-old female, with a history of urticaria developed $1 \mathrm{~h}$ after ceftriaxone injection. ST were positive to penicillin G, amoxicillin, ampicillin, and ceftriaxone, but negative to cefuroxime. DPT to cefuroxime was performed and 5 minutes after the fourth dose (cumulative dose of $42.5 \mathrm{mg}$ ), she had a sensation of malaise, BP dropped to $90 / 60 \mathrm{mmHg}$ (previous BP was 125/80 $\mathrm{mmHg}$ ). Antihistamine $\mathrm{H} 1$ and systemic corticosteroids were given, with improvement of signs/symptoms within $2 \mathrm{~h}$.

Patient no. 3 was a 24-year-old female, with a history of perioperative reaction, labelled as potentially allergic. She presented CV arrest and pulmonary edema during surgery for teeth removal. During DPT 
to dexamethasone, 5 minutes after the fourth dose (cumulative dose of $16.2 \mathrm{mg}$ ), this patient developed hypotension $(70 / 40 \mathrm{mmHg})$ that persisted for $1.5 \mathrm{~h}$. BP control was achieved after intravenous isotonic normal saline. The patient was lost to follow up.

Patient no. 4 was a 32-year-old female, with a history of generalized urticaria developed $2 \mathrm{~h}$ after voluntary tasting cefatrizine (powder mixed in milk for her son). During ST to BL, positive intradermal reaction to the BL-ring was observed, followed by collapse, loss of consciousness, and hypotension.

Supplementary Table 1. Summary table of the patients who presented cardio-vascular symptoms and signs evocative of shock during drug allergy work-up.

Clinical characteristic $(\mathrm{n}=32$ patients)

Male, N (\%)

Mean age at tests $\pm \mathrm{SD}$

Drug allergy work-up ( $\mathrm{n}=36$ reactions) N (\%)

Tested medication

ATB

Beta-lactams

Others ATB

NSAIDs

Paracetamol $^{+}$

Corticosteroids

Biological agents

Others $^{++}$

Type of test

DPT

ST

Chronology of the reaction during the test (after last ingested dose)

$<1 \mathrm{~h}$

$1-6 \mathrm{~h}$

6-24h

Unknown

Categories of symptoms

Cardiovascular (CV)

Mucocutaneous (CU)

Respiratory (RS)

Gastrointestinal (GI)

Systemic (e.g., fever)

Symptom associations

Isolated CVS

$\mathrm{CV}+\mathrm{CU}$

$\mathrm{CV}+\mathrm{CU}+\mathrm{RS}$

$\mathrm{CV}+\mathrm{CU}+\mathrm{GI}$

$\mathrm{CV}+\mathrm{CU}+\mathrm{RS}+\mathrm{GI}$

$\mathrm{CV}+\mathrm{RS}+\mathrm{GI}$

$\mathrm{CV}+\mathrm{CU}+\mathrm{GI}+$ fever

+Paracetamol; 4 with paracetamol, 1 with paracetamol/codeine ++Other; Aspartame, Dihydroergotamine, Lidocaine chlor 